\title{
Constructing Interpersonal Meaning in Indonesian Science Classrooms through Language, Space and Gaze
}

\author{
YULIZAR KOMARAWAN \\ Linguistic Studies, School of Postgraduate Studies, Universitas Pendidikan Indonesia, \\ Jalan Dr. Setiabudi No. 299, Bandung, Indonesia \\ yulizar.komarawan@upi.edu
}

Published online: 15 May 2019

To cite this article: Komarawan, Y. 2019. Constructing interpersonal meaning in Indonesian science classrooms through language, space and gaze. KEMANUSIAAN the Asian Journal of Humanities 26(1): 1-23, https://doi.org/10.21315/kajh2019.26.1.1

To link to this article: https://doi.org/10.21315/kajh2019.26.1.1

\begin{abstract}
Classroom communication involves the integration of various semiotic modes which is linked to particular meanings, like teacher-student relationships or interpersonal meanings. This study investigates the different semiotic resources used in an Indonesian science classroom and the power relations manifested in the classroom through the analyses of different semiotic modes. The present study employed a qualitative case study based on Multimodal Critical Discourse Analysis. The data were recorded videos of a science lesson in a private school located in Lembang, West Java, Indonesia. The data were analysed using the framework of negotiation developed in Systemic Functional Linguistics to investigate language use, spatial pedagogy and gaze. The study found that the observed teacher predominantly produced speech functions in the forms of questions (40 percent), statements (28 percent) and commands (18 percent) while her students predominantly produced answers ( 49 percent) and questions ( 26 percent) during the interactions. In terms of space, the teacher occupied authoritative, personal and interactional spaces while the students mostly occupied the interactional space. With regard to gaze, the teacher's gaze was directed at the students, the objects under discussion and the books, while her students directed their gaze at the teacher, the objects under discussion and the books. These findings reflect a dynamic pedagogy. While the observed teacher maintains her authority most of the time, she focuses on building a rapport or a certain solidarity with her students as reflected in her use of the semiotic resources.
\end{abstract}

Keywords and phrases: multimodal communication, speech function, spatial pedagogy, gaze, power relation 


\section{Introduction}

A classroom is a place of literacy and learning in which highly complex communication occurs and particular relationships are negotiated. Classroom communication flows rapidly and involves many people so it can be difficult to understand everything that is transpiring (Walsh 2011). In addition, the language being used during classroom communication has various functions such as seeking knowledge, questioning something and offering advice (see Walsh 2006; 2011). These varying functions make classroom interactions very complex. Simultaneously, the language used in a classroom establishes particular identities and relationships between the teacher and the students (see Lukmana, Aziz and Kosasih 2006).

As a matter of fact, classroom communication naturally involves various semiotic resources such as body movement, verbiage and image (Taylor 2014). In a similar vein, Kress (1997) describes communication as a product of active engagement with various semiotic resources which are available to users at a particular time and in certain contexts. In the pedagogical context, both teachers and students actively organise the resources available to them to make meaning in a particular way (Kress et al. 2001). Therefore, communication in the learning process involves not only purely linguistic accomplishments, but rather "multimodal accomplishments" (Jewitt et al. 2001, 10).

The notion of classroom communication as a multimodal accomplishment highlights the integration of different semiotic resources for meaning-making. For instance, an English teacher may use simple pictures, verbiages and body movements to achieve the objective of her or his lesson (Sukiyadi, Hermawan and Dallyono 2016). Meanwhile, a science teacher is most likely to use visual, linguistic and actional modes especially when she or he conducts an experiment (Jewitt et al 2001; Jewitt 2005). This perspective provides a new way of conceptualising classroom interaction as a multimodal communication by its very nature (Jewitt 2007).

The term "multimodality" in literacy education is closely related to social semiotics (Halliday 1978; Hodge and Kress 1988). Social semiotics considers meaning-making as a choice made between the available options (Halliday 1978) and emphasises the importance of human beings who actively make choices (Stein 2008). In other words, social semiotics considers meaning-making as a result of active choices from the semiotic modes available to users. From this perspective, multimodality is an act of sign-making involving various semiotic resources to represent relations and events (Kress and van Leeuwen 2006). Thus, multimodal approaches to classroom communication investigate how teachers and students 
select and configure available semiotic resources such as space, visual display and gesture to make meaning in classrooms (Jewitt 2007).

As mentioned earlier, the combinations of different semiotic resources in a communicative act generate particular meanings. Kress et al. (2001) argue that every act of communication realises three types of meaning, that is, ideational, interpersonal and textual meanings. The meanings which are inspired by Halliday's meaning-making principle are called metafunctions (see Halliday and Matthiessen 2014). One of the functions is the interpersonal function which appertains to maintaining and establishing relationships among members of a group. For example, particular semiotic modes such as classroom space and gesture explored and produced by teachers and students in classrooms indicate particular relationships between them.

Research on multimodal communication in science classrooms has been conducted. Jewitt et al. (2001), Kress et al. (2001) and Jewitt (2005) investigated how students transformed or transduced information across different modes. Their findings suggested that students transformed their teacher's description of a cell in their presentation on onion cells (e.g., experimentation into a written report or verbal analogy into a visual analogy). Other related studies focused on multimodal communication to support learning in science classrooms. Villanueva (2016) found that using extra non-linguistic modes may act as a bridge for instructions in science classrooms. In addition, Tang, Ho and Putra (2016) suggested that the orchestration of multimodal literacy activities such as talking, writing, drawing and doing was important in science classrooms. They use the term "disciplinary literacy teaching in science" to refer to this orchestration.

Current studies have examined the role of different semiotic resources in conveying meaning in science classrooms and the integration of different semiotic modes to support learning in these classrooms. However, it appears that studies which focus on investigating the orchestration of multiple semiotic modes for constructing power relations in science classrooms have not yet been explored. The present study addresses this gap. More specifically, this study investigates how the orchestration of multiple semiotic modes constructs power relations. The present study is framed by the following research questions: (1) What types of speech functions are used discursively by a teacher in a science classroom? (2) What types of spatial pedagogy are used discursively in a science classroom? (3) What directions of gaze are found in a science classroom? (4) What kind of power relation is constructed through the use of different semiotic resources? It is hoped that this study will enrich the multimodal literature. Furthermore, the findings of the study will be useful in improving teaching practices in science classrooms. 


\section{Literature Review}

\section{Systemic Functional Linguistics (SFL)}

The theory underpinning the present study is SFL (Martin 1992; Eggins 2004; Halliday and Matthiessen 2014). From this theoretical perspective, language is viewed as a resource for meaning-making (Halliday 1978). Eggins (2004) provides a description of it by stating that meaning-making is a process of choosing a linguistic system which culture makes available to users. In making a choice, what people say or write obtains its meaning "by being interpreted against the background of what could have been meant (said or written in the context but was not)" (Eggins 2004, 20).

In SFL, language is theorised into three types of language functions called metafunctions which consist of ideational, interpersonal and textual functions (Martin 1992; Eggins 2004; Halliday and Matthiessen 2014). Ideationally, language can be used to construe experiences or express users' perceptions of the world. At the same time, language is used textually to create coherent and cohesive discourse and used interpersonally to enact social relationships among speakers (Bloor and Bloor 2004). Each function is realised through different grammatical resources. Since this study investigates interpersonal meaning, the resources realising this function will be further elaborated.

Interpersonal meanings at discourse semantic level are realised through negotiation, appraisal and involvement (Martin and White 2005). In particular, this study will only discuss negotiation. Martin and Rose (2007) define negotiation as "an exchange between speakers: how speakers adopt and assign roles to each other in dialogue and how moves are organised in relation to one another" (219). The moves that speakers produce create an exchange. When speakers exchange information or goods, they use speech functions. There are four basic types of speech function. Those are statement, question, offer and command (Eggins and Slade 1997; Martin and Rose 2007; Barlett 2014; Halliday and Matthiessen 2014). These speech functions are called initiating speech functions and their role is to start a conversation. As a rule, the initiations will be followed by responses produced by the interlocutors. The responses can be an "acknowledgement" which shows a positive response to a statement, an "acceptance" which shows a positive response to an offer, an "answer" which indicates a positive response to a question, "compliance" which shows agreement with a command, "contradiction" which demonstrates disagreement with a statement, "rejection" which indicates disagreement with an offer, a "disclaimer" which indicates ignorance of a statement and a "refusal" which shows a denial of a command (Lukmana et al. 2006; Martin and Rose 2007; Halliday and Matthiessen 2014). 


\section{Multimodality}

In this study, multimodality is defined as an act of communication using different semiotic modes (Kress et al. 2001). Furthermore, Iedema (2003) states that multimodality "highlight[s] the importance of taking into account semiotics other than language-in-use, such as image, music, gesture and so on" (33). Thus, multimodal research mainly investigates how different semiotic modes such as image, verbiage and gesture are integrated and organised to make meaning.

Nowadays, educators and researchers should integrate multimodal perspectives in their analysis of classroom communication. This is because face-to-face interaction in the classroom involves "simultaneous engagements with at least the modalities of speech, written texts, visuals, space and body language" (Hood 2011, 31). Multimodality offers a way of analysing co-existing, multiple semiotic resources and their roles in great detail (Iedema 2003). Thus, a multimodal perspective provides opportunities for researchers to analyse how teachers and students engage actively with available modes at the same time. By combining all the aspects of these modes, researchers can obtain a deeper insight into the pedagogical process and how classroom experiences are constructed for the students (Lim, O'Halloran and Podlasov 2012, 235).

The non-linguistic resources which are significant to the present study are classroom space and gaze. Classroom areas which are occupied by teachers are significant semiotic resources for pedagogic discourse (Lim et al. 2012). The use of classroom space through the teacher's movement helps to establish interpersonal meaning or relationships between teachers and students and so does the use of gaze. In a science classroom, gaze is commonly used to manage the learning process and simultaneously to establish a particular identity.

In the context of education, classroom space can be divided into four different types of space (Lim et al. 2012). Those are authoritative and/or personal, supervisory, surveillance and interactional space. The proposal of these categories is based on one of Hall's proxemic spaces, namely social-consultative space. The authoritative space is located in the centre of the front of the classroom by the teacher's desk. This is the area where teachers are positioned to perform formal teaching, to give instructions and facilitate a lesson. The supervisory space is located along the rows of students' desks and up and down the side of the classroom. This is the place where teachers patrol to check students' activities. The surveillance space is located within the supervisory space. In this place, teachers implicitly maintain their extreme power and control. The interactional space is described as the place where teachers stand alongside students' desks or between the rows of students' 
desks. This is the area where teachers interact with their students and the students carry out their tasks (Lim 2011; Lim et al. 2012).

Gaze is also an important semiotic resource in establishing interpersonal meanings or relationships in classrooms. Gaze can be defined as "visible action" in which participants show that they are paying attention (Kendon 2009, 359). Therefore, gaze can be used to engage interlocutors in a conversation. From a conversational analysis perspective, gaze has several functions. For example, gaze may signal turn-taking. In other words, it indicates that the turn is approaching completion. It is also used to pressure interlocutors to provide responses to what speakers say (Rossano, Brown and Levinson 2009) and to monitor human beings' behaviour during interaction (Virkkula-Räisänen 2014).

Currently, gaze has received attention in systemic functional and social semiotic studies. In this field, Amundrud (2017) demonstrates how speakers use gaze to enact a social relationship. His study found that transactional gaze in individual feedback consultations can occur in the following directions: teacher to student, student to teacher, teacher to class, teacher or student to a shared document, and teacher and student to a shared document. The direction of gaze together with the functions of the gaze are used as a point of departure for analyses.

Nowadays, multimodality is becoming more common in Critical Discourse Analysis (hereafter CDA), creating a new approach called Multimodal Critical Discourse Analysis (MCDA) (Ledin and Machin 2018). The researchers working with MCDA adopt and apply the assumption and method in CDA to multimodal texts. CDA assumes that power and ideology are negotiated and transmitted through discourse. To investigate power and ideology, critical discourse analysts describe linguistic features. In particular, it focuses on why and how the features are produced (Machin and Mayr 2012) and relates them to wider contexts. Similar to CDA, MCDA "denaturalise[s] representation on other modes of communication" (Machin and Mayr 2012, 9) such as images, texts and music. In other words, it seeks to investigate the discourses buried in texts or interactions to uncover the kind of ideologies and power relations they represent (Ledin and Machin 2018). Thus, MCDA is quite different from the study known as Multimodal Discourse Analysis (MDA) in terms of purpose. MDA describes the features of semiotic resources such as visual, aural or gestural features and the relations between the resources or intersemiosis while MCDA goes beyond describing the features and relations of semiotic modes. It seeks to reveal the ideology or power relation reflected in the choices of the features in the multimodal texts or interactions. 


\section{Method}

The study utilised a qualitative approach to investigate power relations as manifested in a science classroom through analyses of the orchestration of different semiotic modes. The study considered these power relations as a central phenomenon which requires exploration and understanding (Creswell 2012). In terms of design, the study used a descriptive case study. As described by Yin (2003), a descriptive case study has the purpose of presenting a deep and detailed picture of a particular phenomenon. In this study, the phenomenon is power relations which reside in a science classroom.

The present case study was conducted in a private school located in Lembang, West Java, Indonesia. This school features two types of curricula. In practice, the school combines both the National Curriculum known as K13 or Kurikulum 2013 and the Cambridge International General Certificate of Secondary Education (IGCSE) O Level. In this school, teachers are encouraged to design engaging learning activities. They are also encouraged to develop their professionalism through workshops, training or short courses hosted by national or international organisations, so that they can improve their teaching competencies and their teaching can meet 21 st century learning outcomes.

The data used in the present study were videos of a science classroom lesson. The duration of the videos is about 26 minutes. To obtain a detailed insight into the learning activities, cameras at the back and front of the classroom were used to record the learning. The cameras recorded the overall activities of the class and specific activities of selected students. The topic covered in the learning activity was about acid and base delivered by a female teacher named Jelita (pseudonym) who has taught for five years and has had training in STEM (Science, Technology, Engineering and Mathematics) education.

The data were then analysed within the MCDA paradigm (Machin and Mayr 2012; Ledin and Machin 2018) using several frameworks to obtain a clear picture of the power relations within the observed classroom. The framework of negotiation developed within SFL was used to identify speech functions during the interactions. The spatial pedagogy developed by Lim et al. (2012) was applied to see the teacher's position relative to her students or vice versa and the concept of gaze as discussed by Rossano et al. (2009) and Kendon (2009) was taken into account. Those resources are crucial in defining the tenor of the discourse, namely science classroom communication. 


\section{Speech Function in the Science Classroom}

The interpersonal meanings which exist in science classrooms can be understood by investigating classroom interactions. As discussed earlier in the literature review, teachers may use various speech functions when they teach. Those speech functions reflect the meaning of speakers' utterances, namely whether speakers are posing questions, making statements, offers or commands (Halliday and Matthiessen 2014). Detailed examination of the language used in the classroom revealed that various speech functions were produced by the teacher. This result is consistent with the work of Walsh (2011). In his book, Walsh (2011) describes that teachers may use language which performs several functions when they teach. Furthermore, the analyses found that the observed teacher and students produced quite different speech functions from each other. The teacher commonly produced initiating speech functions while the students mostly produced responses to the initiating speech functions. The speech functions produced during the lesson under investigation are summarised in Table 1.

Table 1. Summary of speech functions in the science classroom

\begin{tabular}{lcccccc}
\hline \multirow{2}{*}{ Speech function } & \multicolumn{2}{c}{ Teacher } & & \multicolumn{2}{c}{ Students } \\
\cline { 2 - 3 } \cline { 5 - 6 } \cline { 5 - 6 } Statement & Frequency & \% & & Frequency & $\%$ \\
Offer & 25 & 28 & & 1 & 1 \\
Question & 2 & 2 & & - & - \\
Command & 36 & 40 & & 18 & 26 \\
Acknowledgement & 16 & 18 & & 1 & 1 \\
Answer & - & - & & 6 & 9 \\
Compliance & 11 & 12 & & 34 & 49 \\
Rejection & - & - & & 8 & 12 \\
Refusal & - & - & & 1 & 1 \\
\hline Total & - & - & & 1 & 1 \\
\hline
\end{tabular}

As Table 1 shows, the teacher frequently produced initiating speech functions in terms of questions (40 percent), statements ( 28 percent), commands (18 percent) and offers ( 2 percent). A question was used to check the students' understanding. A statement was produced when the teacher described the concepts that should be mastered by her students. A command was used to instruct the students to do something. Meanwhile, the students frequently produced speech functions in the form of preferred responses such as an answer (49 percent), compliance 
(12 percent), acknowledgement (9 percent) and negative responses such as denial ( 1 percent) and refusal (1 percent). As a general rule, the students produced answers in response to the questions produced by the teacher. At some point, however, the students also produced initiating speech functions in terms of questions (26 percent), commands ( 1 percent), and statements ( 1 percent). From a critical stance, the findings reflect certain relationships between the teacher and her students, which will be further elaborated below.

As mentioned earlier, the teacher frequently used questions during the lesson. The students then responded to her question. This situation is exemplified in Excerpt [a] below.

\section{Excerpt [a]: Teacher's questions}

$\mathrm{T} \quad$ : OK, do you remember what is acid and alkali?

S : Yes.

$\mathrm{T} \quad$ : Yes, what is the $\mathrm{pH}$ of acid?

SSS : Seven, ten, oh seven.

$\mathrm{T} \quad$ : Do you still remember all right; do you still remember whether vinegar is acid or alkali?

SSS : Acid.

Excerpt [a] shows an example of a "question" produced in the classroom. The question is typically signalled by interrogative clauses and grammatically realised through the order (Wh-) ${ }^{\wedge} \mathrm{F}^{\wedge} \mathrm{S}^{\wedge} \mathrm{P}$ (see Bloor and Bloor 2004). Commonly, the question is used to check students' understanding and elicit responses from the students (Walsh 2006). This is consistent with the findings of the present study in which the teacher asked questions to elicit the students' verbal responses in the science classroom. The questions were positively responded to by the students using a speech function called an "answer". At the exploration stage, the teacher asked her students a number of questions about the given concepts. In doing so, she was able to control the turn-taking. A critical perspective suggests that this situation reflects an asymmetrical relationship. The teacher maintains her authority and controls the classroom interaction (Wang 2006).

Before asking questions, the observed teacher commonly described the concepts of $\mathrm{pH}$ to her students. She used a speech function called "statements" when describing the concepts as exemplified in Excerpt [b]. 
Excerpt [b]: Teacher's statements

$\mathrm{T}$ : Today, well actually you won't do nothing eh you won't do anything ya in this class, you just watch.

$\mathrm{S}$ : Yes.

$\mathrm{T}$ : And observe what happened to the solutions where I will drop some substances called phenolphthalein. Actually I would like to find a red cabbage, but unfortunately, I cannot find here one in Lembang or anywhere, so well it can show a beautiful, four beautiful colours of the solutions ya.

Well, maybe on Monday, I will let you know about red cabbage. So, for now, we'll only use the phenolphthalein.

Excerpt [b] shows an example of statements during the lesson. The statement is typically indicated by declarative clauses and grammatically realised through the order $\mathrm{S}^{\wedge} \mathrm{F}^{\wedge} \mathrm{P}$. In a pedagogical context, a statement is generally used when teachers describe materials or transmit knowledge. It seems to be neutral when a teacher produces many statements since she or he is a controller of knowledge. However, detailed examination of classroom talk revealed that the observed teacher produced long declarative clauses or statements containing many words. The long statements were only responded to by a very short answer "yes" called an "acknowledgement" which shows agreement with the statements. Through a critical lens, this situation shows an unequal power relation between them since the teacher produced many words compared to her students (Lukmana et al. 2006).

Another speech function was also produced by the teacher in the classroom interaction. This can be seen in Excerpt [c] below.

Excerpt [c]: Teacher's instructions

$\mathrm{T}$ : OK, next.

Next. Go back to your seat.

OK. Some of them are acid, some are alkali. Yang mana yang acid?

$\mathrm{S}: A k u$.

$\mathrm{T}$ : Now we go to page. Number 14 aja. Gampang, a b c.

$\mathrm{S}$ : Yang mana? 
Excerpt [c] exemplifies the use of "commands". The command is typically indicated by imperative clauses and grammatically realised by "the main verb with no visible mood element" (Barlett 2014, 96). Commands or instructions are usually used to organise physical learning (Walsh 2006; 2011). In that extract, the observed teacher explicitly told her students to do something such as to sit down and to go to the next page. As with questions, commands or instructions indicate strong control over interlocutors. This means the one using them has power in a given situation. Thus, it may be concluded that the teacher revealed strong authority at this stage.

However, there may be some indications that in certain situations it was the students who exercised control over the interaction. It has been acknowledged in the literature that one of the common strategies used to exercise power is to initiate a conversation (e.g., Wang 2006). This study found that some students initiated a conversation in the interactional space. The initiation was reflected in the use of students" questions such as "what page?" and "di buku tulis?"; the questions were then patiently answered by the teacher. This situation entailed control over the conversation. Moreover, the students' negative responses played a crucial role in understanding the power struggle. This study found that the students refused to do the given tasks. This can be seen from the speech functions "refusal" and "rejection", which are realised through the interjections "aaaa... or yaah miss". The teacher then responded to that interjection by saying "It's okay you still have time". The interjections showed a rebellious action in which the students refused to obey the instructions. All of these situations seem to indicate control over interactions and the existence of a power struggle between the students and the teacher. Simultaneously, the situation also showed solidarity between the teacher and the students since the teacher was not angry with her students about their behaviour and allowed her students to ask her questions.

\section{Spatial Pedagogy in the Science Classroom}

This section describes the use of classroom space through the teacher's positioning and movement. Detailed analysis of video and classroom observation revealed that the observed teacher spent most of her time in the authoritative space located in the central-front part of the classroom as shown in Figures 1(a) and (b). In this area, she described the concept of $\mathrm{pH}$, acids and bases to her students as shown in Figure 1(a). She also conducted an experiment in this area to test the $\mathrm{pH}$ of solutions as shown in Figure 1(b). The use of classroom space here as demonstrated by the teacher is a common phenomenon where teachers foreground the didactic nature of instruction. 
The fact is that the use of spatial arrangements in classrooms is not neutral (Kenkmann 2011). As reviewed earlier, the authoritative space located right in front of the students refers to the area where teachers provide instructions to facilitate lessons and conduct formal teaching. The area indicates "formality, given the power relations which are established through spatial distance" (Lim et al. 2012, 242). It means that teachers are maintaining and exercising their power when they explore this area. Obviously, they establish a professional relationship with their students there ( $\operatorname{Lim} 2011$ ). It may be concluded that the observed teacher was demonstrating her power and building a professional relationship with her students when she was in the authoritative space.

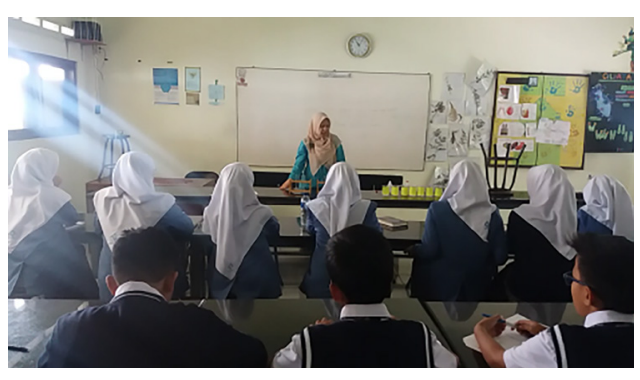

(a)

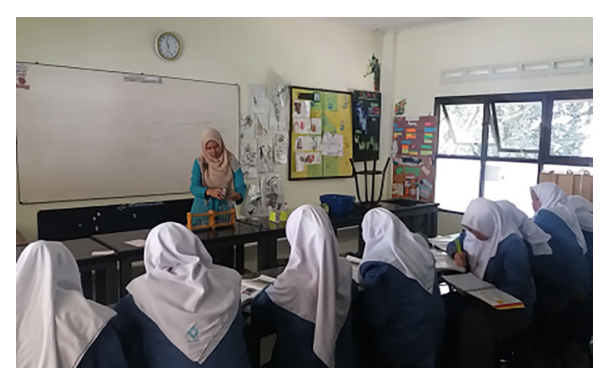

(b)

Figure 1. (a) Explaining materials in the central-front part of the classroom and (b) demonstrating a procedure in the central-front part of the classroom

In classrooms, teachers may move to other places to mitigate the power domination which is realised through occupying the central-front part of the classroom. The analyses showed that the observed teacher moved around the students' desks as shown in Figure 2(a) and (b). She crossed the authoritative space and then approached her students to check their work and ask them if they had problems. As Lim (2011) and Lim et al. (2012) described, this area, known as the interactional space, is the place where teachers offer consultations on the given task. Exploring this area makes the teachers available and accessible to their students who probably have questions related to the given materials. In doing so, they are also able to create proximity with their students. As a result, the interpersonal distance between the teacher and the students is decreasing. Further examination revealed that the students actively interacted with the teacher when she was around them in this area. She answered every question patiently. This suggested that the teacher was building a personal relationship with her students. Through a critical lens, this condition shows the teacher's solidarity with her students and power distribution in the classroom. 
Although the observed teacher occupied the interactional space during the lesson, she did not stay there as long as she stayed in the authoritative space. This may indicate that she was still thinking about maintaining her position as a class manager who had the responsibility of managing her lesson. Therefore, she moved back to the authoritative space where she had strong power to control interactions.

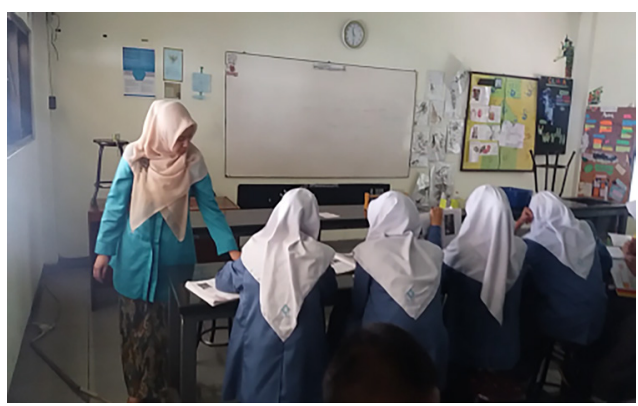

(a)

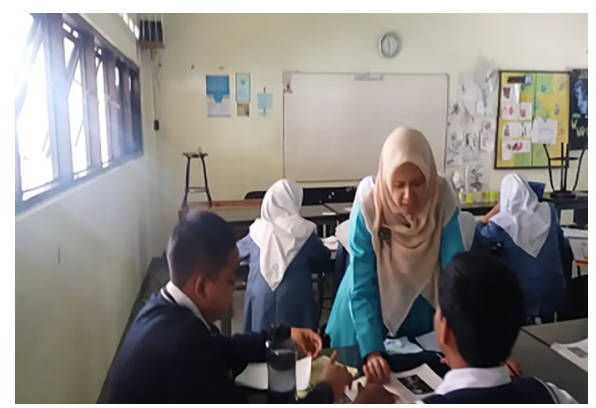

(b)

Figure 2. (a) Interactional space-front row and (b) interactional space-back row

In addition, during the lesson, the teacher moved to the area called the personal space as shown in Figure 3. Lim et al. (2012) describe the personal space as an area where teachers prepare materials for the next stage. They suggest that the area is behind the teacher's desk. In the present study, however, the personal space is located alongside the left row of the students. In this area, various teaching resources are located. Theoretically, this area should be categorised as the supervisory space since this is an area where teachers patrol to check everything. However, it is considered to be the personal space since the teachers prepare teaching materials there. This supports Lim's (2011) notion that physical space in classrooms may not always have a single function.

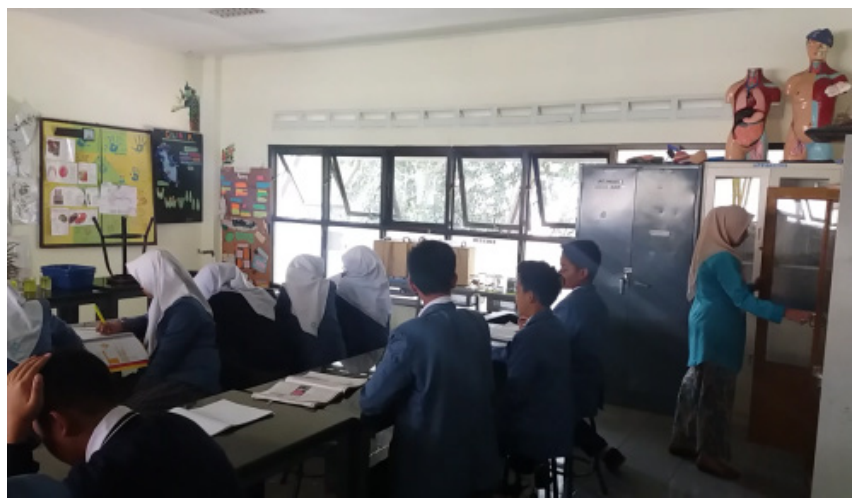

Figure 3. The personal space 
In summary, the study found that the teacher occupied three types of spatial pedagogy as discussed by Lim (2011) and Lim et al. (2012). Those areas are the authoritative, personal and interactional spaces. She occupied the authoritative space for about 18 minutes. Interpersonally, this demonstrates that the teacher exercised her power and authority. She then spent about 7 minutes in the interactional space interacting with her students. A transition from the authoritative space to the interactional space indicates that there is a transition from a formal to an informal learning process. This condition shows an uncommon situation demonstrated by the teacher. Commonly, teachers take control over interaction and this is reflected in their use of the authoritative space for the entire lesson. In this case, however, the observed teacher did not fully exercise control over the interaction because she moved to the interactional space to engage with her students. This means the teacher still considers building a rapport with her students while she adopts a more authoritative pedagogy.

\section{Gaze in the Classroom}

Gaze plays an important role in interaction (see Rossano et al. 2009; Kendon 2009) including in science classrooms. Gaze directed at a speaker signals that a hearer acknowledges that the speaker is taking a turn in a conversation (Goodwin 1980). Gaze indicates that speakers and hearers are actively engaged in interactions. In the present study, gaze is one of the most prominent semiotic resources observable. Based on the classroom observation and analyses of the video, the study found that transactional gaze occurred in the following directions: Teacher to Student $(\mathrm{T}>\mathrm{S})$; Teacher to Object under Discussion $(\mathrm{T}>\mathrm{O})$; Teacher to Books $(\mathrm{T}>\mathrm{B})$; Students to Teacher $(\mathrm{S}>\mathrm{T})$; Student to Student $(\mathrm{S}>\mathrm{S})$; Students to Object under Discussion $(\mathrm{S}>\mathrm{O})$; Students to Books $(\mathrm{S}>\mathrm{B})$; Teacher and Student to Objects $(\mathrm{T}, \mathrm{S}>\mathrm{O})$; Teacher and Students to Books $(\mathrm{T}, \mathrm{S}>\mathrm{B})$; and Students to Somewhere $(\mathrm{S}>\mathrm{Sw})$.

Further analysis revealed that the transactional gaze which frequently occurred during the interactions was $(\mathrm{T}>\mathrm{S}),(\mathrm{T}>\mathrm{O}),(\mathrm{S}>\mathrm{T}),(\mathrm{T}, \mathrm{S}>\mathrm{O})$ and $(\mathrm{T}, \mathrm{S}>\mathrm{B})$. Transactional gaze from $(\mathrm{T}>\mathrm{S}),(\mathrm{T}>\mathrm{O})$ and $(\mathrm{S}>\mathrm{T})$ as shown in Figure 4 was identified when the teacher described the concept of $\mathrm{pH}$. The teacher and students directed their gaze at one another. The students recognised when it was the teacher's turn to talk. They gave their focus to the given description. Simultaneously, the teacher's gaze was directed at the students. This indicates that the teacher was monitoring her students. Virkkula-Räisänen (2014) states that one of the functions of gaze is to monitor human behaviour. This kind of gaze is commonly identified in the authoritative space during the exploration and question-answer stages. In doing so, the teacher was able to exercise her power and control over the students and everything in the classroom. 


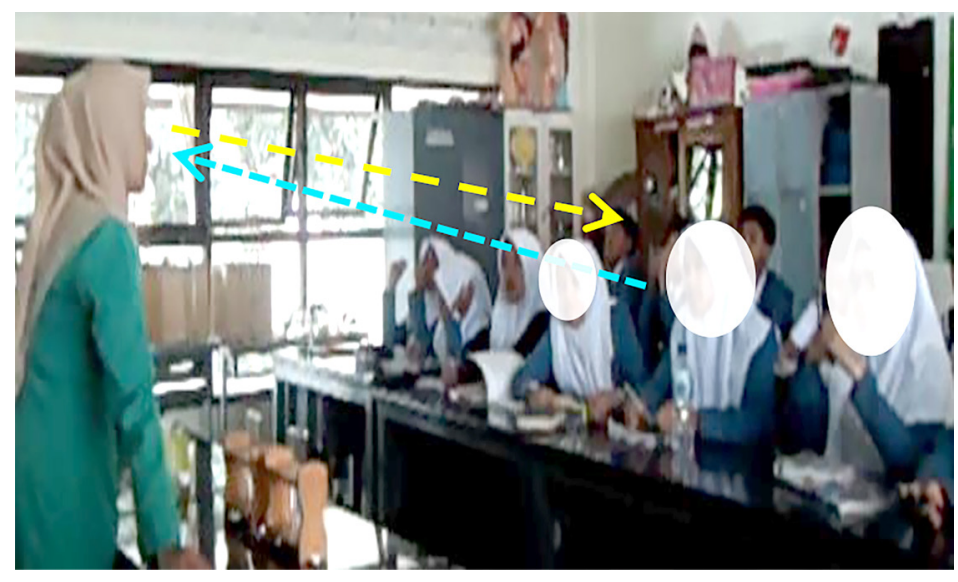

Figure 4. Gaze: $\mathrm{T}>\mathrm{S}$ and $\mathrm{S}>\mathrm{T}$

In addition, the study identified that the teacher and students sometimes directed their gaze to the object under discussion $(\mathrm{T}, \mathrm{S}>\mathrm{O})$ as shown in Figure 5 , or to the books $(\mathrm{T}, \mathrm{S}>\mathrm{B})$ as shown in Figures 2(a) and (b). This transactional gaze was commonly identified when the teacher involved her students in classroom activities such as doing an experiment or when she described tasks to students in the interactional space. They focused on the object under discussion and on the books which became the central focus. This indicated that they were actively engaged with the objects. In doing so, the teacher was able to build a personal relationship or closeness with her students. Thus, gaze plays a crucial role in creating closeness or maintaining social relations between the teacher and her students in the classroom.

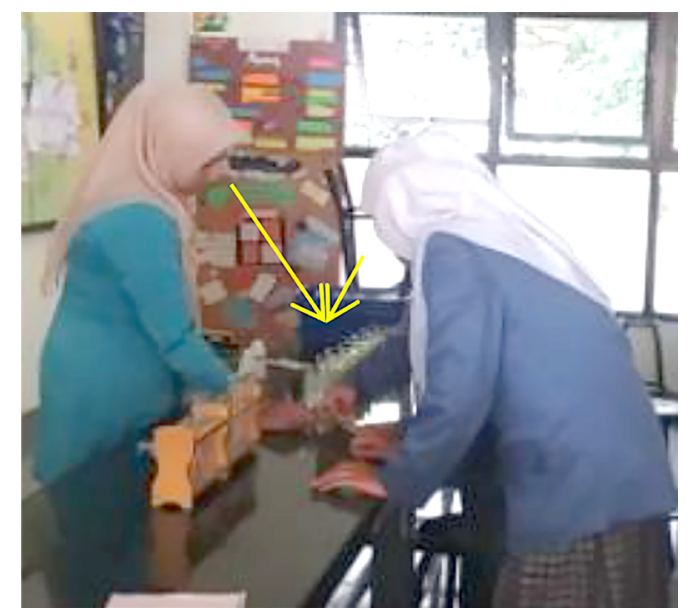

Figure 5. Gaze: $\mathrm{T}, \mathrm{S}>\mathrm{O}$ 
To summarise, the roles of gaze identified in the present study are to monitor the students' behaviour and to create solidarity. The teacher used gaze to monitor her students' behaviour especially when she described the given materials. This can be said to be the teacher demonstrating her authority or power in the teaching process. However, she also used her gaze to engage with her students especially when she conducted an experiment and interacted with her students in the interactional space. The situation indicated that she managed to build closeness and increased solidarity with her students. Like the use of space, the use of gaze also indicates that she considers building a rapport with her students to be important, while she adopts a more authoritative pedagogy.

\section{Co-Deployment of the Semiotic Resources}

This section provides a brief description of the linguistic choices and gaze used together in particular areas. In other words, it provides an integrative view of how the orchestration of different semiotic resources realises interpersonal meanings in science classrooms. It should be noted here that this section only provides a very short illustration of the orchestration. A deep and comprehensive analysis of the combination of different resources is beyond the scope of this paper. In the literature, the integration of multiple semiotic resources is called intersemiosis (O'Halloran 2005), intersemiotic complementary (Royce 2006) or multiplying meaning (Lemke 1998). Particularly, this section presents the co-deployment of the semiotic resources in the authoritative and interactional spaces as displayed in Table 2 and Table 3.

Table 2. Gaze and verbiage in the authoritative space

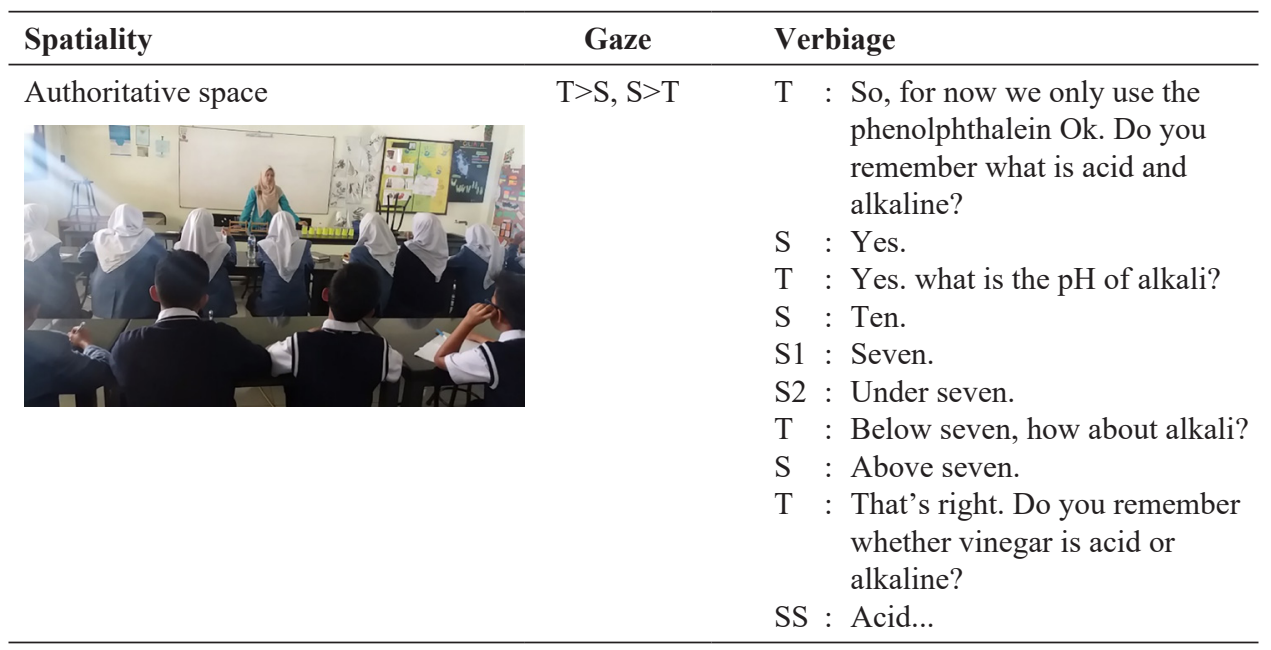


As shown in Table 2, the teacher produced questions in the authoritative space. When asking questions, she directed her gaze at her students. This indicates that she was monitoring them and expecting them to respond to her questions. In this circumstance, she was trying to emphasise her role as a classroom manager. The construction of strong authority was then complemented and strengthened by her use of classroom space. As discussed previously, the use of the authoritative space in an interpersonal way shows the formality of teaching in which teachers show their control over classroom interaction and build a professional relationship. The activated meanings from different modes reinforce the degree of interpersonal meaning in the classroom. This is what Lemke (1998) called "multiplying meaning" across modes.

Table 3. Gaze and verbiage in interactional space

\begin{tabular}{|c|c|c|}
\hline Spatiality & Gaze & Verbiage \\
\hline Interactional space & $\begin{array}{c}\mathrm{T}>\mathrm{S}, \mathrm{S}>\mathrm{T} \\
\mathrm{S}, \mathrm{T}>\mathrm{B}\end{array}$ & 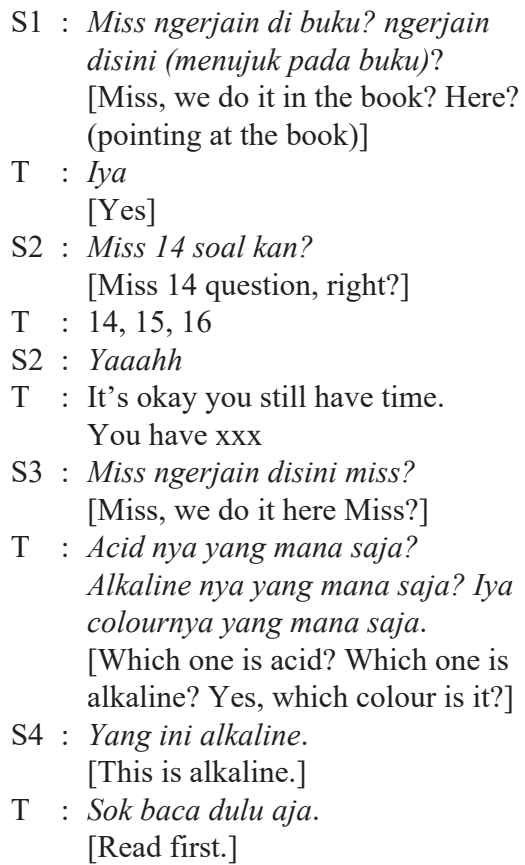 \\
\hline
\end{tabular}

Unlike the teacher's use of speech functions in the authoritative space, the teacher did not only produce initiation speech functions in the form of statements and questions, but also responded to the questions from her students in the interactional space. The teacher decreased her control over the interactions by allowing her students to ask questions. Doing this made students more engaged in the classroom interactions. This is consistent with the nature of the interactional 
space. Furthermore, the interactional gaze used in this space shows the teacher's engagement with her students. The teacher's gaze was directed at her students and she was actively engaged with the books. The activated meanings from three different resources demonstrated a close relationship between the teacher and her students.

The short description presented above illustrates how three different semiotic resources are co-deployed at one point in a lesson. They collaborate to strengthen and multiply interpersonal meanings. In this case, what the teacher and her students say, how they direct their gaze at one another and how they use space during the lesson collaborate to reinforce meaning. As a result, "the integrated meaning is greater than the sum of one individual mode on its own (i.e., multiplying of the meaning)" (He and Forey 2018, 188).

\section{Building Power Relations}

In this study, the concept of power is associated with that discussed in CDA. In CDA, power is about the relationship between differences among participants. This means there will be members of a more powerful group who has access to or control over some public discourses and a less powerful group who has less access to means of discourse production (Wang 2006). Furthermore, power is "central for understanding the dynamics and specifics of control (of action) in modern societies" (Wodak and Meyer 2009, 10). Control is achieved through the ideological workings of language (Fairclough 1989). It is believed within the field of CDA that language can be used to express and challenge power as well as to alter the distribution of power either in the short or long terms. Language can also be used to establish differences in power in a hierarchical social structure.

However, the present study revealed that differences in power were also reflected in the use of other semiotic resources. The previous section has described how language, particularly speech functions, space and gaze are used to manage a science lesson in an Indonesian classroom. It has been understood that the use of particular speech functions (Lukmana et al. 2006), spatial arrangement (Kenkmann 2011; Lim et al. 2012) or gaze (Amundrud 2017) reflect a certain interpersonal meaning such as a power relation and solidarity.

The study found that the teacher produced many questions during the lesson. In the classroom, she asked her students questions related to $\mathrm{pH}$, acid and base such as "OK, do you remember what is acid and alkali? Yes, what is the $\mathrm{pH}$ of acid? Do you still remember alright?" and "Do you still remember whether vinegar is acid 
or alkali?"; she expected the students' responses to confirm their understanding. In the pedagogical context, the use of questions makes her a teacher questioner. The questions position her as the knower and her students as those without knowledge in the classroom (Brooks 2015). Simultaneously, the questions also indicate an establishment of a discourse position. According to Halliday and Matthiessen (2014) and Wang (2006), a question is commonly employed to open a conversation, which involves control and the establishment of position in a conversation. Thus, it may be said that the teacher adopted a role as controller in the classroom.

The teacher also produced other speech functions to manage her lesson. It was found that the observed teacher used commands during the lesson. She asked her students to do something such as "you can bring this", "OK, next please, stop!", "It has a strong smell, go back to your seat", "open your book at page 150" and "coba baca itu baca [try to read that one] how to detect acid". Under these circumstances, students were placed in the position of fulfilling what their teacher wanted. By directing her students in explicit ways, the teacher was maintaining her authority over and social distance with her students. This suggests that there exists a social divide and a power difference between them. The nature of the teacher's talk here indicates that she maintains control over knowledge and classroom interaction. This condition reflects what Brooks (2015) called a teacher-centred paradigm of the contemporary classroom.

Power relations are also reflected in the use of space and gaze. Kenkmann (2011) states that space is never neutral. It means that the use of space indicates power. In the science classroom, as shown in this study, the teacher predominantly occupied the authoritative space which made her more powerful because this area shows authority or the formality of the teaching process. Furthermore, strong power or authority is reflected in the dominant use of gaze directed at the students and objects. She used transactional gaze to monitor the students' behaviour during the exploration stage in the classroom.

In the last stage of the learning process, however, the teacher shared power with her students. This can be seen when the teacher occupied the interactional space. In this area, she made herself available to her students and patiently answered every question coming from her students. In doing so, she was able to build a personal relationship or closeness with her students. This solidarity is also reflected in her reactions in response to the deviant gaze shown by some students. She did not do anything when her students sometimes ignored her and did not follow her instructions. This condition suggests that the students are starting to get into a power struggle and the teacher seems to be accepting the struggle. 
It could be said here that power relations in this classroom are dynamic. The teacher established a strong power or authority at the beginning of her lesson. At that stage, she produced long statements to describe the materials, asked her students many questions about the given concept and instructed them to do something. In addition, during that stage she dominantly used a monitoring gaze and explored the authoritative space. Interpersonally, the use of the speech functions, together with the monitoring gaze and the use of the authoritative space, shows the formality of teaching with which she maintains control over classroom interaction and establishes a professional relationship. She then shared the power with her students in the last stage of her teaching. She allowed her students to ask her questions and occupied the interactional space. As discussed earlier, the use of these resources indicates that she was foregrounding solidarity or building a rapport with her students. It seems that the observed teacher is demonstrating a dynamic pedagogy when delivering the lesson.

\section{Conclusion}

The present study investigates semiotic modes used in an Indonesian science classroom and how power relations are manifested in the classroom through the analyses of different semiotic modes. The study found that the teacher dominantly produced questions, statements, commands and answers while the students provided responses to the speech functions and produced questions. As regards spatial pedagogy, the study found that the teacher spent her time in the authoritative, personal and interactional spaces, while the students spent most of their time in the interactional space. In terms of gaze, the teacher directed her gaze at her students, the documents (books) and the objects while her students directed their gaze at the teacher, the documents and the objects. These results suggested that the teacher was a questioner and director while the students were responders. This condition may also suggest that the teacher demonstrates strong authority or power in the science classroom. However, the teacher decreased her power domination by allowing her students to ask her questions and by occupying the interactional space to build closeness. It seems that the power relation in this classroom is dynamic. Initially, the teacher tried to demonstrate her power. She then shared power with her students and built solidarity with her students at certain stages. It is clear that the observed teacher maintains a powerful or authoritative pedagogy most of the time. However, in the last stages of her teaching she focuses on building rapport, as reflected in her use of the semiotic resources. It may well be argued that she is demonstrating a dynamic pedagogy. 
This paper has illustrated how different semiotic resources such as verbiage, gaze and space play a significant role in constructing interpersonal meanings in science classrooms. As discussed earlier, the resources helped the observed teacher to build an identity as a powerful classroom manager or director and establish solidarity in the classroom. It appears that understanding how to use semiotic resources in the classroom may be useful for teachers. By having good information about exploring semiotic resources, they can get better at classroom management, since they know how to establish solidarity with the students and how to become a powerful classroom manager at different stages.

Although the findings of the study seem to be insightful and illuminating, they cannot be generalised to every science classroom. As discussed in the research method, this study is a single case study of one teacher over a 26-minute lesson. To make a valid generalisation, further studies should be conducted. Perhaps, further studies can focus on multiple cases and analyse longer lessons to get a clearer picture of how power relations are manifested in classrooms through the analyses of different semiotic resources. Similarly, further studies should include other data collections such as interviews with teachers and students to support the arguments. By doing so, it is expected that the findings will be more convincing and reliable.

\section{References}

Amundrud, T.M. 2017. Analyzing classroom teacher-student consultations: A systemic multimodal perspective. Unpublished PhD dissertation, Macquarie University.

Barlett, T. 2014. Analysing power in language. London: Routledge.

Bloor, T. and Bloor, M. 2004. The functional analysis of English: A Hallidayan approach (2nd ed.). London: Arnold.

Brooks, C.F. 2015. Role, power, ritual, and resistance: A critical discourse analysis of college classroom talk. Western Journal of Communication 80(3): 1-22. https://doi. org/10.1080/10570314.2015.1098723

Creswell, J.W. 2012. Educational research: Planning, conducting, and evaluating quantitative and qualitative research (4th ed.). Boston: Pearson.

Eggins, S. 2004. An introduction to systemic functional linguistics (2nd ed.). New York and London: Continuum.

Eggins, S. and Slade, D. 1997. Analysing casual conversation. London: Equinox.

Fairclough, N. 1989. Language and power. New York: Longman.

Goodwin, C. 1980. Restarts, pauses, and the achievement of mutual gaze at turn-beginning. Sociological Inquiry 50(3-4): 272-302. https://doi.org/10.1111/j.1475-682x.1980. tb00023.x

Halliday, M. 1978. Language as a social semiotic: The social interpretation of language. London: Edward Arnold. 
Halliday, M. and Matthiessen, C. 2014. Halliday's introduction to functional grammar (4th ed.). London and New York: Routledge.

He, Q. and Forey, G. 2018. Meaning-making in a secondary science classroom: A systemic functional multimodal discourse analysis. In Global developments in literacy research for science education, eds. Kok-Sing Tang and K. Danielsson, 183-202. Switzerland: Springer. https://doi.org/10.1007/978-3-319-69197-8_12

Hodge, R. and Kress, G. 1988. Social semiotics. Cambridge: Polity Press.

Hood, S. 2011. Body language in face-to-face teaching: A focus on textual and interpersonal meaning. In Semiotic margins: Meaning in multimodalities, eds. S. Dreyfus, S. Hood and M. Stenglin, 31-52. New York: Continuum.

Iedema, R. 2003. Multimodality, resemiotization: Extending the analysis of discourse as multi-semiotic practice. Visual Communication 2(1): 29-57. https://doi. org/10.1177/1470357203002001751

Jewitt, C. 2005. Classrooms and the design of pedagogic discourse: A multimodal approach. Culture Psychology 11(3): 309-320. https://doi. org/10.1177/1354067x05055519

2007. A multimodal perspective on textuality and contexts. Pedagogy, Culture and Society 15(3): 275-289. https://doi.org/10.1080/14681360701601937

Jewitt, C., Kress, G., Ogborn, J. and Tsatsarelis, C. 2001. Exploring learning through visual actional and linguistic communication: The multimodal environment of a science classroom. Educational Review 53(1): 5-18. https://doi. org/10.1080/00131910123753

Kendon, A. 2009. Language's matrix. Gesture 9(3): 355-372. https://doi.org/10.1075/ gest.9.3.05ken

Kenkmann, A. 2011. Power and authenticity: Moving from the classroom to the museum. Adult Education Quarterly 61(3): 279-295. https://doi. org/10.1177/0741713610392766

Kress, G. 1997. Before writing: Rethinking the paths to literacy. London: Routledge.

Kress, G., Jewitt, C., Ogborn, J. and Tsatsarelis, C. 2001. Multimodal teaching and learning: The rhetoric of the science classroom. New York: Continuum. https://doi. org/10.3138/cmlr.72.1.152

Kress, G. and van Leeuwen, T. 2006. Reading images: The grammar of visual design (2nd ed.). New York: Routledge.

Ledin, P. and Machin, D. 2018. Multi-modal critical discourse analysis. In The Routledge handbook of critical discourse analysis, eds. J. Flowerdew and J.E. Richardson, 6070. London and New York: Routledge. https://doi.org/10.4324/9781315739342-5

Lemke, J.L. 1998. Multiplying meaning: Visual and verbal semiotics in scientific text. In Reading science: Critical and functional perspective on discourses of science, eds. J.R. Martin and R. Veel, 87-113. London and New York: Routledge.

Lim, F., O'Halloran, K. and Podlasov, A. 2012. Spatial pedagogy: Mapping meanings in the use of classroom space. Cambridge Journal of Education 42(2): 235-251. https://doi.org/10.1080/0305764x.2012.676629

Lim, F.V. 2011. A systemic functional multimodal discourse analysis (SF-MDA) approach to classroom discourse. Unpublished $\mathrm{PhD}$ dissertation, National University of Singapore. 
Lukmana, I., Aziz, A.E. and Kosasih, D. 2006. Makna interpersonal dalam interaksi gurumurid: Sebuah kajian wacana kritis. Linguistik Indonesia 24(1): 11-22.

Machin, D. and Mayr, A. 2012. How to do critical discourse analysis: A multimodal introduction. London: Sage.

Martin, J.R. 1992. English text: System and structure. Amsterdam: John Benjamin.

Martin, J.R. and Rose, D. 2007. Working with discourse: Meaning beyond the clause (2nd ed.). London: Continuum.

Martin, J.R. and White, P.P.R. 2005. The language of evaluation: Appraisal in English. New York: Palgrave MacMillan.

O’Halloran, K.L. 2005. Mathematical discourse: Language, symbolism and visual images. London and New York: Continuum.

Rossano, F., Brown, P. and Levinson, S.C. 2009. Gaze, questioning and culture. In Conversation analysis: Comparative perspectives, ed. J. Sidnell, 187-249. Cambridge: Cambridge University Press. https://doi.org/10.1017/ cbo9780511635670.008

Royce, T. 2006. Intersemiotic complementarity: A framework for multimodal discourse analysis. In New directions in the analysis of multimodal discourse, eds. T.D. Royce and W.L. Bowcher, 63-109. Mahwah, NJ: Lawrence Erlbaum. https://doi. org/10.4324/9780203357774

Stein, P. 2008. Multimodal pedagogies in diverse classrooms: Representation, rights, and resources. New York: Routledge. https://doi.org/10.4324/9780203935804

Sukiyadi, D., Hermawan, B. and Dallyono, R. 2016. Transduction and transformation of semiotic resources in an English classroom. Malaysian Journal of ELT Research 12(1): 60-72.

Tang, K.-S., Ho, C. and Putra, G.B.S. 2016. Developing multimodal communication competencies: A case of disciplinary literacy. In Using multimodal representation to support learning in the science classroom, eds. B. Hand, M. McDermott and V. Prain, 135-158. New York: Springer. https://doi.org/10.1007/978-3-319-164502_8

Taylor, R. 2014. Meaning between, in and around words, gestures and postures: Multimodal meaning-making in children's classroom discourse. Language and Education 28(5): 401-420. https://doi.org/10.1080/09500782.2014.885038

Villanueva, M.G.F. 2016. Using multimodal representations to develop scientific literacy in South African classrooms. In Using multimodal representations to support learning in the science classroom, eds. B. Hand, M. McDermott and V. Prain, 77-96. New York: Springer. https://doi.org/10.1007/978-3-319-16450-2_5

Virkkula-Räisänen, T. 2014. Linguistic repertoires and semiotic resources in interaction: A Finnish anger as a mediator in a multilingual meeting. Journal of Business Communication 47(4): 505-531. https://doi.org/10.1177/0021943610377315

Walsh, S. 2006. Investigating classroom discourse. New York: Routledge.

2011. Exploring classroom discourse: Language in action. New York: Routledge.

Wang, J. 2006. Questions and the exercise of power. Discourse Society 17(4): 529-548.

Wodak, R. and Meyer, M. 2009. Methods of critical discourse analysis. London: Sage.

Yin, R.K. 2003. Case study research: Design and methods. Thousand Oaks, CA: Sage Publication. 